\title{
Application of ISO/TS 16949:2009 in Forest Products Industry
}

\author{
Ertan SOLAK ${ }^{1},{ }^{*}$ Derya SEVIM KORKUT ${ }^{2}$ \\ ${ }^{1}$ Forest Industry Engineer, Düzce, Turkey \\ ${ }^{2}$ Duzce University Faculty of Forestry, Department of Forest Industry Engineering, \\ Konuralp Campus, 81620, Düzce-Turkey \\ *Corresponding Author: deryasevimkorkut@duzce.edu.tr
}

Geliş Tarihi: 03.03.2016

\begin{abstract}
The aim of the study is to present the short, medium and long term benefits of the activities in the basis of quality management development and in the context of ISO/TS 16949 Automotive Sub-Industry Quality Management System which determines the service standards of a forest products facility as an automotive sub-industry supplier, to be shown as an example to similar facilities. In this study which aims to present the facility's character an examination has been done via supplier, production and customer parameters and an example profile has been formed. A progress on the activities which are made in accordance with the project plan about improving production parameters such as in-process junk, customer satisfaction, customer return and staff circulation rate has been determined. The dynamics of forest production sector presents a critical factor about sufficiency of the suppliers. This parameter is followed by supplier's performance point and even if expected level is reached the activities about this subject continues according to project plan. Customer satisfaction rate is determined by annual performance points given by customers and the facility reaches the expected level according these parameter data.
\end{abstract}

Key Words: Automotive sub-industry facility, Forest products industry, Quality, Quality management system, ISO/TS 16949

\section{Orman Ürünleri Endüstrisinde ISO/TS 16949:2009’un Uygulanması}

\section{Özet}

Çalışmanın amacı, orman ürünleri iş kolundaki bir işletmenin, otomotiv yan sanayi olarak sağladığı hizmet standartlarını belirleyen TS ISO 16949 Otomotiv Yan Sanayi Kalite Yönetim Sistemi kapsamında kalite yönetim sisteminin gelişimi temelinde gerçekleştirdiği faaliyetlerin işletmeye kısa, orta ve uzun vadede sağlayacağ faydaları benzer konumdaki işletmelere örnek teşkil edecek şekilde ortaya koymaktır. İşletme karakterinin ortaya konulmasını amaçlayan bu çalışmada süreç adımlarını oluşturan tedarikçi, üretim ve müşteri parametreleri üzerinden bir inceleme yapılarak örnek bir profil oluşturulmuştur. İşletmenin proses içi hurda, iç müşteri memnuniyet, müşteri iade ve personel devir oranı gibi üretim parametrelerinin iyileştirilmesi yönünde proje planı doğrultusunda yaptığ faaliyetlerde ilerleme sağladığı tespit edilmiştir. İçinde yer alınan orman ürünleri sektörünün dinamikleri çalışılmak durumunda kalınan tedarikçilerin yeterliliği konusunda kritik bir etken oluşturmakta, tedarikçi performans puanı ile izlenen bu parametrede beklenen düzeye belli ölçüde ulaşılsa dahi bu konuda yapılması gereken çalışmalar proje planı doğrultusunda sürdürülmeye devam etmektedir. Müşteri memnuniyet oranı yıllık olarak müşteri tarafından verilen performans puanı üzerinden izlenmekte, işletme bu parametre verilerine göre beklenen düzeye ulaşmış bulunmaktadır.

Anahtar Kelimeler: Otomotiv yan sanayi, Orman ürünleri endüstrisi, Kalite, Kalite yönetim sistemi, ISO/TS 16949

\section{Introduction}

Even though an enterprise is giving service in a sector which is assumed to remain in the background both nationally and internationally because of negative features in terms of regional and sectoral conditions (busy working difficulty, uneducated labor force, lack of innovation, producing products with low added-value, profit oriented view of the bosses), because it is the supplier of automotive key industry it would be possible to perform this thesis survey about quality management system development and the benefits of the development to the enterprise. This study, which is very important in terms of forming a reference with the help of the route after the research of the national position of the enterprise, consists of 4 main parts. In the first part, quality and other concepts related to it were explained and details about theoretical basis of the thesis study were determined. In the second part, the enterprise which is chosen as an example and its sector were introduced in general 
terms, the developing activities which were done by taking ISO/TS 16949 Automotive Subordinating Industry Quality Management System as reference and the side effects of these activities towards application were dealt. In the third part, the improperness which was determined after the main and interim audits done every year by a third independent audit corporation and the regulations within the scope of the quality management system were discussed and corrective activities were studies. At the last part, the data which was obtained for the application during the research was evaluated and some suggestions were made within the context of future planning. Before forming the basic structure of the study, a literature research based on two main subject titles, which were determined before, has been carried out on national data base. Firstly, three studies have been determined in the research about "the relationship between forest products industry and quality", they have been summarized above and they have been evaluated. According to this; Saçlı (2007) made a study about basically about contributions of the total quality management to productivity by a frame practice study in a panel furniture production business in his postgraduate thesis. Buluç (2009) in his postgraduate thesis; researched the structure of ISO 9000 Quality Management System, its application steps and its contributions to the facility. Tass (2010) had a research about a sample practice of process FMEA (Failure Mode and Effects Analysis) for furniture industry which is one of the types of FMEA in his postgraduate thesis. In the second phase, three studies have been determined as a result of a research named "ISO/TS 16949 Automotive Sun-Industry Quality Management System", the studies have been summarized above and they have been evaluated. According to this; Erdoğan (2008) indicated that the quality systems being created were combined by ISO/TS 16949:2002 in order for the firms to give the products and service which were accepted by the whole of the world in his postgraduate thesis. He also indicated in his thesis that they can survive long in automotive sector which is one of the most competitive sectors of all if they catch a specific level on quality and price. Özden (2009) researched ISO/TS 16949 Automotive Quality Management System which is one of the most common systems in automotive industry according to product design and quality effect. After researching this system, he aimed to determine the acquisitions and negative effects of the system. Batmaz (2010) researched the theoretical substructure of Total Quality Management and ISO/TS 16949 Quality Management System and then he identified the situation by exemplification according to the data obtained from the firms using these management systems. According to the outline which after the scanning the literature the theoretical substructure of the study has been formed after researching quality and related concepts. It was required to give place the definitions of two basic sources related to quality concept. According to this; Quality was defined as meeting the conditions of existing characteristics in ISO 9000;2000 standards series (Peker, 2014). If the International Organization for Standardization- ISO quality dictionary is taken as reference, the quality concept will be defined as the combination of the features based on determined or possible needs (Türker, 2014). Quality concept is so important for both industry and service sector today and it began to be perceived as "convenience to usage" except from "convenience to technical conditions", it gained meaning with the view of consumers and it began to be perceived as "supplying the customers' needs" (Akdere et al., 1994). Today, quality concept is not only for service and product, but it is also about the quality of the management, because the quality of the product or service is related to the process. From this point of view quality isn't a technical term anymore, now it is a strategic term (Özveren, 1997). It is possible to gather all related ingredients into three groups. These are; design, convenience and performance (Taşçı et al., 2013).

The extent of the quality is divided into 8 basic titles; performance, equipment, reliability, convenience, durability, service opportunities, aesthetic and perceived quality (Kaya and Engin, 2005). When we separate quality from theoretical structure, we have four basic concepts related to each other. 
These basic concepts have been mentioned below. According to this; Quality Control is the activities done according to the defined conditions and defining the mistakes to achieve the production properly and the activities to see the trends and the techniques used (Zairi, 1993). Quality Assurance is applying all the planned and systematical activities in the scope of quality system and defining the adequate trust for the company to perform the quality conditions (Şenyuva, 2008). Quality system consists of business goals, the process that helps to reach these goals and business resources those make business activities run (Sarıkaya, 2003). Quality management is the system that uses the information effectively by coordinating labor force in the business, satisfies the customers by combining technical and management tools and helps fulfilling economical quality costs (Feigenbaum, 1983). ISO/TS 16949 is an ISO Technical Specification. ISO/TS 16949 achieves the objectives which are continually to improve the production of automobile parts and related services, and to strengthen the international competition for the automotive industry and its suppliers (Ostadi et al., 2010). ISO/TS 16949:2009 Automotive Side Industry Quality Management System has been developed as a result of cooperation of International Automotive Task Force-IATF, Japan Automobile Manufacturer Association-JAMA and ISO/TC 176 technical comity (URL 1, 2014). It presents some activities such as how to design the production management, how to identify all critical phases and how to improve these phases' parameters (Mcatee, 2002).

\section{Material and Methods}

In the company serving for automotive subordinating industry, in accordance with technical files of which design is completely belongs to costumers carry out production of wall of separation located in the bus interior, parcel shelf, hostess cabinet, climbing ramp, the cabinet above the driver, driver berths, pallets, crates in factory where established 2950 square meters closed area by 15 administrative and 22 production staff in a medium-sized labor-intensive enterprises by working five days a week in accordance to single shift system covering nine hour working time in daily. The enterprise uses three basic groups of inputs. These are; raw material (medium density fiberboard plywood, lumber, laminate, ABS/PVC folio, block board), auxiliary material and packing materials. Production process consists of some stages; cutting, pressing, covering, shaping and installation. The enterprise doesn't give and installation or service duty after selling process but customer complaints is being evaluated actively. From the enterprises located in production activities, progress based on continuous improvement in the framework of these conditions are expected based on conditions determined by the main industry is serviced as subordinate industry. This expectation, as in every enterprise, has been found provision in accordance with sector and operating conditions. As the company started operations on the day, in accordance with its business contracts which will provide service as subordinate industry. According to received reference as main text with ISO 9001 Quality Management System its works in the field of documentation and applications and by determining as the destination ISO 16949 Automotive Industry Quality Management System and quality of customer specific requirements has been working in this direction. All documentation and application data used in the thesis were obtained by working in a position that carrying responsibility of quality management system within the company and were evaluated in this study objectively. Five basic process management system of which substructure has been built according to the customer expectations those are obliged by ISO/TS 16949 Automotive Side Industry Quality Management System standards has been being applied. Advanced Product Quality Planning (APQP) application which is a structural method that ensures to identify and actualize the necessary steps to fulfill customer satisfaction. The plant benefits from a planning schedule to record plannedactualized times and responsibilities. Failure Mode and Effects Analysis (FMEA) study is done to predetermine possible failures about the product and take enough precautions to eliminate the risks and the results are 
recorded. Statistical Process Control (SPC) applications are used to ensure desired quality conditions, determine failure formation during the process and amend the process. This application consists of tabulating the quality indicators in statistical process control graphics and observing the process. In the process to put every product into use Measurement Systems Analyze (MSA) applications has been being used to assure that critical characteristics has been measured correctly, to analyze the perfection of the tools used to measure. A systematical structure called Production Part Approval Process (PPAP) has been being used to make the suppliers understand the engineering, design drawings and specifications determined by the customer in a proper way. With PPAP it is ensured to fulfill the necessities for product and system quality in pre-production process.

\section{Results and Discussion}

The enterprise which tries to supply the improvement in the application area and the development of the quality management system in accordance with the plan formed mutually with the customer since its foundation, saw in which position it stands with the help of a third independent audit corporation which is approved by the customer and had the chance to determine their future development and investment plans. The nonconformities, which was determined by a third independent audit company with main and interim audits, has been detected as suggestion for improving the process by the project team and some positive reactions were obtained within the quality management system of the enterprise. There were two audits in a year time, one main and one interim, in the enterprise. The features below which are thought for the enterprise to protect in third party control to be done in the concept of documentation process and which are thought to have the potential for developing have been emphasized specifically.

$\checkmark$ Substructure opportunities,

$\checkmark$ Customer focused,

$\checkmark$ Working environment's supporting innovation,

$\checkmark$ Adaptation performance of senior management and administrative staff during working process.

Within the scope of this control it has been revealed that document control process hasn't been used effectively with not identifying external document revision system clearly. As part of the corrective action about the subject an investigation about supplier, customer, legal and commercial based external document tracking list has been done. A revision tracking system has been formed, responsible people has been assigned and necessary revision has been completed. It has been proved that process description isn't totally active via the proof that has been reached about the fact that some process performance criterion hasn't been determined clearly in terms of activity and productivity. Within the scope of corrective action about the subject process parameters has been studied. After some parameter have been added and some parameters have been eliminated the necessary revision has been completed. The process has been completed by carrying out some trainings and improvement activities with the related responsible.

The enterprise determined to aim lasting the existence of the document by grounding on the customers' expectations and standard conditions and it also determined to continue constant developing activities. In the study, the data which concerns last five years period of performance parameters including recovery time of the business management and this data has been shown in the Table 1 below. Below the Table 1 the business` route and their recovery goal for the next year at the end of 2013 has been shown. 
Table 1. Annual change of duration performance parameters (Solak, 2014)

\begin{tabular}{|c|c|c|c|c|c|c|c|}
\hline \multirow{2}{*}{$\begin{array}{c}\text { Process } \\
\text { Performance } \\
\text { Parameters }\end{array}$} & \multirow{2}{*}{ Calculation Formula } & \multirow{2}{*}{$\begin{array}{l}\text { Planned } \\
\text { (P) / } \\
\text { Realised } \\
\quad(\mathbf{R})\end{array}$} & \multicolumn{5}{|c|}{ Years } \\
\hline & & & 2009 & 2010 & 2011 & 2012 & 2013 \\
\hline \multirow{2}{*}{$\begin{array}{c}\text { The Ratio of } \\
\text { making the offers } \\
\text { orders }\end{array}$} & \multirow{2}{*}{$\begin{array}{l}\text { (Order number / Offer } \\
\text { number)*100 }\end{array}$} & $\mathbf{P}$ & $35 \%$ & $40 \%$ & $42 \%$ & $45 \%$ & $60 \%$ \\
\hline & & $\mathbf{R}$ & $38 \%$ & $42 \%$ & $42.5 \%$ & $67.09 \%$ & $68 \%$ \\
\hline \multirow{2}{*}{$\begin{array}{l}\text { The ratio of } \\
\text { fulfilling the orders }\end{array}$} & \multirow{2}{*}{$\begin{array}{l}\text { (The number of the } \\
\text { products delivered to } \\
\text { the customer/ The } \\
\text { numbers of the } \\
\text { orders)*100 }\end{array}$} & $\mathbf{P}$ & $100 \%$ & $100 \%$ & $100 \%$ & $100 \%$ & $100 \%$ \\
\hline & & $\mathbf{R}$ & $92 \%$ & $92 \%$ & $95 \%$ & $98 \%$ & $98 \%$ \\
\hline \multirow{2}{*}{ In Process scrap } & \multirow{2}{*}{$\begin{array}{c}\text { (Scrap number / product } \\
\text { number)*1000000 } \\
(\mathrm{ppm})\end{array}$} & $\mathbf{P}$ & 11500 & 11000 & 10000 & 10000 & 9000 \\
\hline & & $\mathbf{R}$ & 11480 & 10700 & 10180 & 9293 & 8780 \\
\hline \multirow{2}{*}{ In process repair } & \multirow{2}{*}{$\begin{array}{c}\text { (Repair number / } \\
\text { product } \\
\text { number } * 1000000 \\
(\mathrm{ppm})\end{array}$} & $\mathbf{P}$ & - & - & 13000 & 13000 & 13000 \\
\hline & & $\mathbf{R}$ & - & - & 13420 & 13200 & 13220 \\
\hline \multirow{2}{*}{$\begin{array}{c}\text { The ratio of } \\
\text { machine pauses } \\
\text { because of failure }\end{array}$} & \multirow{2}{*}{$\begin{array}{l}\text { (The ratio of machine } \\
\text { pauses because of } \\
\text { failure/ Total working } \\
\text { duration of the } \\
\text { machines)*100 }\end{array}$} & $\mathbf{P}$ & $6 \%$ & $6 \%$ & $6 \%$ & $6 \%$ & $6 \%$ \\
\hline & & $\mathbf{R}$ & $6.40 \%$ & $6.20 \%$ & $6.40 \%$ & $6.30 \%$ & $6.40 \%$ \\
\hline \multirow{2}{*}{$\begin{array}{c}\text { Performance ratio } \\
\text { of supplier }\end{array}$} & \multirow{2}{*}{$\begin{array}{c}\text { (Delivery point } \\
/ 100) * 40+(\text { Quality } \\
\text { point/100)*50+(Extra } \\
\text { freight point } / 100) * 10\end{array}$} & $\mathbf{P}$ & $95 \%$ & $95 \%$ & $95 \%$ & $95 \%$ & $95 \%$ \\
\hline & & $\mathbf{R}$ & $92.7 \%$ & $92 \%$ & $92.53 \%$ & $\begin{array}{c}93.67 \\
\%\end{array}$ & $\begin{array}{c}94.62 \\
\%\end{array}$ \\
\hline \multirow{2}{*}{$\begin{array}{l}\text { Return from the } \\
\text { customers }\end{array}$} & \multirow{2}{*}{$\begin{array}{c}\text { (Returned product } \\
\text { number / Total number } \\
\text { of the products } \\
\text { delivered to the } \\
\text { customers })^{*} 1000000 \\
(\mathrm{ppm})\end{array}$} & $\mathbf{P}$ & 1300 & 1200 & 1000 & 750 & 500 \\
\hline & & $\mathbf{R}$ & 1250 & 1020 & 859 & 598 & 436 \\
\hline \multirow{2}{*}{$\begin{array}{l}\text { The ratio of } \\
\text { answering } \\
\text { customers } \\
\text { complaints }\end{array}$} & \multirow{2}{*}{$\begin{array}{l}\text { (Answered complaint } \\
\text { number / Total } \\
\text { complaint number) } * \\
100\end{array}$} & $\mathbf{P}$ & $100 \%$ & $100 \%$ & $100 \%$ & $100 \%$ & $100 \%$ \\
\hline & & $\mathbf{R}$ & $88 \%$ & $87 \%$ & $92 \%$ & $96 \%$ & $98 \%$ \\
\hline \multirow{2}{*}{$\begin{array}{c}\text { Circulation of the } \\
\text { staff ratio }\end{array}$} & \multirow{2}{*}{$\begin{array}{l}\text { (The number of quitting } \\
\text { staff/ Total staff number) } \\
* 100\end{array}$} & $\mathbf{P}$ & $5 \%$ & $5 \%$ & $5 \%$ & $4 \%$ & $3 \%$ \\
\hline & & $\mathbf{R}$ & $7 \%$ & $7 \%$ & $4 \%$ & $4 \%$ & $2 \%$ \\
\hline \multirow{2}{*}{$\begin{array}{c}\text { Process circulation } \\
\text { ratio }\end{array}$} & \multirow{2}{*}{ Labor day } & $\mathbf{P}$ & 3 & 3 & 3 & 3 & 3 \\
\hline & & $\mathbf{R}$ & 7 & 7 & 6 & 4 & 4 \\
\hline
\end{tabular}


The ratio of making the offers order was $38 \%$ in 2009 but in the three years period till 2012 it became closer to $70 \%$ because it is a commercial parameter that is between customer needs and top management, it is also variable. The decision of dispatching by using Regal (steel cage) system via contractual logistics firm, defining the products in the scope of the revision extent and the outcome of the reformation activities on monitoring have been actualized with the confirmation of the customer at the end of 2012. With the effect of these reformation activities the ratio of fulfilling the orders which was $92 \%$ in 2009 made progress in a positive way and it became $98 \%$ at the end of 2013. With the help of the training for the development towards the goal of forming auto control principal of beginning, middle and final control thought and substructure activities in process scrap number was decreased under $9000 \mathrm{ppm}$ on 10000 lines in 2013. After 2010 in process repair number has been become a process performance parameter, with the trainings and documentation substructure it became controllable and at the end of 2013 the business has reached the aimed ppm value with the value of 13220. As a result of the analysis studies, informative field trainings and the budget a specific turnout has been caught but the pauses of the machines couldn't be decreased under $6 \%$. With the help of correct business unions and productive data analysis during the reformation process, supplier performance ratio has been increased to $94.62 \%$ in 2013 from $92 \%$ level but the goal couldn't be reached which was $95 \%$. The expectations of the main industry were taken as priority during the reformation process and individual responsible was determined by forming effective communication ways. At the same time, with the help of the trainings given to the staff about understanding and directing the customers' needs customer return ratio has been reduced below $500 \mathrm{ppm}$ in 2013, before it was through 1000 lines. Another parameter related to the subject is answering the customers' complaints, it has been increased to $98 \%$ in 2013 from $90 \%$. In the light of sectoral and local conditions one of the most important problems is circulation of the staff. During the revision period the trainings of the management staff had positive impact on the workers, their sense of belonging, recovering the working conditions of the workers and development of the relations in accordance with the customers' requests. With the help of these and new projects commercial bounds with the customers have been strengthened and this rate has been decreased from $7 \%$ in 2007 to $4 \%$ in 2011 and in 2013 it was $2 \%$. Minimizing the duration of the process which consists of analyzing the returned pieces by the customer, control, production or engineering units, deciding whether to repair or reproduce, doing the decision and delivering it to the customer is accepted as very important process parameter. In this parameter, the expectations of the customers stand out and they are the determiners. In this scope, the circulation time has been estimated as 3 days in this study and it has been determined as the goal. With the analysis about the parameter in 2009 the circulation was determined as 7 days, in 2013 it was reduced to 4 days.

\section{Conclusions}

The quality management system, which will be applied according to a systematic and planned process, will supply the chance for the enterprise to evaluate new opportunities and work on these opportunities in a planned way. The suggestions of the auditors during the certification process have been considered and evaluated objectively within the scope of this thesis study and the suggestions below have been determined. The data was included in the project plan within the context of constant improving plan and working plans have been determined oriented to be carried out:

$\checkmark$ The substructure of the quality management system documentation should be improved constantly and consisted documentation sufficiency should be shown in the application field effectively.

$\checkmark$ Theoretical training programs should be done frequently in the application field and blue-collar staff should attend the training programs. Perceived mistakes 
should be included in the structure of analysis results system documentation.

$\checkmark$ While choosing a blue-collar and whitecollar staff some criteria such as their educational level, qualities and continuation should be paid attention and the integration of the new staff should be one of the most important subjects on which the enterprise should work on for the continuity of the system.

$\checkmark$ Because of the current structure and customer portfolio of the corporation, some studies should begin oriented to "product design and development" which the corporation leaves aside of documentation, after forming process structure about this subject raising customer satisfaction and market share should be aimed.

$\checkmark$ The enterprise should take ISO 14001 Environment Management System and ISO 18001 Occupational Health and Safety Management System standardization as aim and should carry on some studies in this subjects giving importance to legal expectations.

$\checkmark$ The suggestion and reward system that is built for increasing the attendance of every personnel that are assigned inside the plant to the continuous improvement operations should be actively used unlike the current conditions and improvement operations should be made based on the positive feedbacks from this system.

$\checkmark$ The company which is unable to intervene the product criteria of the key industry as a result of their current condition, should start a progress in the medium term about the "product design and development" subject that is currently out of the contents of documentation and along with building process structure, increasing customer satisfaction and market share must be aimed.

$\checkmark$ As the company is switching within the ISO TS 16949:2009 Automotive Supply Industry Quality Management System, the operations in the short term should be focusing on internal trainings, letting the employees attend on decision phases, managing the subsidiarity implementations properly, and take the right steps for letting every personnel that are assigned inside the plant adopt this new managerial structure which includes a vast number of new data, even if they are resistant in the beginning.

$\checkmark$ The improvement studies on the quality management system and the processes that have been worked in detail in the beginning should be summarized in accordance with company requirements and standard expectations, some of the processes should be combined and some of them should be canceled, and the process supervisors should be taken on an effective and dominant position with internal training and field studies provided.

$\checkmark$ With the aim of improving current defining and traceability system and minimizing the mistake rate, substructure investment should be found, computer controlled barcoding system should be set, current material program should be integrated and tracking the product delivery should be enabled.

\section{Acknowledgement}

This study is a part of Master Science Thesis prepared by Ertan SOLAK, Graduate School of Natural and Applied Sciences, Duzce University, Duzce, Turkey.

\section{References}

Akdere F., Aksoy M.H., Candas E., Polat M.H., Psaropulos M., Yilmaz İ.H. 1994. Total quality management perspective of Turkey (Applications, problems-opportunities and recommendations), Istanbul: Total Quality Management Research Committee, Uniform Publishing.

Batmaz C., 2010. Study About ISO/TS 16949 Quality management system in automotive sector with total quality management perspective including investigation in machining industry. M.Sc. Thesis, Marmara University Institute of Social Science, 138 p. Istanbul-Tukey.

Buluç S., 2009. Creation of the implementation phase and documentation structure of TS EN ISO 9000:2008 quality management system in a furniture factory. M.Sc. Thesis, Bartın University Institute of Sciences, 165 p. Bartın-Turkey.

Erdoğan Ö., 2008. ISO/TS 16949:2002 automotive quality management system and a case study in an automotive supplier firm. M.Sc. 
Thesis, Marmara University Institute of Social Science, 211 p. Istanbul-Turkey.

Feigenbaum A., 1983. Total Quality Control. McGraw-Hill.

Kaya İ., Engin O., 2005. Use of artificial intelligence techniques in quality improving process. Pamukkale University Engineering College, Journal of Engineering Sciences, 11 (1), 103-114.

Mcatee M. 2002. Perspectives on TS ISO 16949:2002 implementation exploring ISO/TS 16949. The Automotive Industry Action Group.

Ostadi B., Aghdasi R., Kazemzadeh R.B., 2010. The impact of ISO/TS 16949 on automotive industries and created organizational capabilities from its implementation. Journal of Industrial Engineering and Management, 3(3), 494-511, (doi:10.3926/jiem.2010.v3n3.p494-511

Özden D., 2009. Examination of product development process in the context of ISO 16949 quality system and application examples. M.Sc. Thesis, Marmara University Institute of Fine Arts, 167 p. Istanbul-Turkey.

Özveren M., 1997. Total quality management (Basic concepts and applications), 1st Edition, Istanbul: Alfa Press Release Distribution.

Peker D., 2014. ISO 9001:2000 Quality management system, informatics association of Turkey, Public IT Platform X, 1. Working Group, http://www.tbd.org.tr/usr_img/cd/kamubib15/rap orlarPDF/RP1-ISO9001-2008.pdf (Accessed: June 26, 2014).

Saçlı C., 2007. The impact of total quality management on productivity a framework implementation at an enterprise producing panel furniture. M.Sc. Thesis, Dumlupinar University Institute of Sciences, 155 p. Kütahya-Turkey.

Sarıkaya N., 2003. Total quality management. 1st Edition, Sakarya: Sakarya Bookstore

Şenyuva H.Z., 2008. Analytical quality assurance: Minimum requirements, http://www.bornovavet.gov.tr/pdf/6BVKAEHZS ENYUVA.pdf (Accessed: June 26, 2014).

Solak E., 2014. TS ISO 16949:2009 quality management system and application in a forest products enterprise. M.Sc. Thesis, Düzce University Graduate School of Natural and Applied Sciences, p.174, Düzce-Turkey.

Taş Y., 2010. The application of the failure mode effects analysis to furniture industries. M.Sc. Thesis, Istanbul University Institute of Sciences, 198 p. Istanbul-Turkey.

Taşçı D., Eroğlu E., Çabuk S.Y., Duman G., Ağlargöz O., Erdemir E., Özsoy E.A. 2013. Quality management systems. Anadolu University Publication No: 2810, Open Education Faculty Publication No: 1768, ISBN 978-975-061475-0.
Türker V., 2014. Quality management system,http://www.volkanturker.com.tr/pdf/iskurkalite.pdf (Accessed: June 26, 2014).

URL 1, 2014.

http://www.kalitera.com.tr/kalite.asp?groupID=5 \&productID=13.htm (Accessed: April 08, 2014)

Zairi M., 1993. Total Quality Management. Gulf Publishing Company. 